\title{
Understanding Refugee Mental Health and Employment Issues: Implications for Social Work Practice
}

\author{
Lindsey Disney, PhD, LCSW \\ University at Albany, SUNY, Albany, New York, United States \\ Jane McPherson PhD, MPH, LCSW \\ University of Georgia, Athens, Georgia, United States \\ Contact: $\underline{\text { ldisney@albany.edu }}$
}

\begin{abstract}
Resettled refugees have high rates of some mental health disorders, such as PTSD and MDD, largely due to trauma histories and current resettlement stressors. Resettled refugees also have employment struggles that are unique to their status as refugees. This article provides overviews of refugee mental health and refugee employment issues with a specific focus on how these factors are interrelated in U.S. resettled refugee populations. The article describes prevalence rates of mental health disorders among refugees, barriers that limit refugees' access to mental health treatment, and evidence-based mental health. Additionally, prevalence rates of refugee unemployment and underemployment are reported, along with barriers to adequate refugee employment. The article concludes with recommendations for social work professionals in their practices with resettled refugees in multiple settings: clinical practice, refugee resettlement, policy work, and research.
\end{abstract}

Keywords: refugee; mental health; employment; unemployment; underemployment; clinical social work; resettlement; community-based interventions

Date Submitted: March 20, 2020 | Date Published: September 9, 2020

\section{Recommended Citation}

Disney, L., \& McPherson, J. (2020). Understanding refugee mental health and employment issues: Implications for social work practice. Journal of Social Work in the Global Community, 5, 19-30.

https://doi.org/10.5590/JSWGC.2020.5.1.02

\section{Introduction}

Social workers practicing with refugee communities resettled in the U.S. have historically needed to choose between (1) clinical or trauma-focused practice and (2) case management or social adjustment-focused practice (Miller \& Rasmussen, 2010, 2014). However, more recently, scholars are arguing that refugee populations require a more holistic approach that combines individual mental health treatment and the case management services that support successful resettlement (Engstrom \& Okamura, 2004; Nazzal, 2014; Miller \& Rasmussen, 2010, 2014). This shift in thinking can be traced to Miller and Rasmussen's (2010) "War exposures, daily stressors, and mental health" conceptual model, which sought to expand upon the traumafocused models that conceptualized war traumas as the sole predicator of poor mental health by including "daily stressors" as a concurrent predictor. While Miller and Rasmussen were clearly not the first researchers to consider the negative effects of long-term, cumulative stress on mental health, their model provided an 
Disney \& McPherson, 2020

integrative approach to understanding the interplay between trauma histories, current daily stressors, and mental health for refugee populations.

Numerous post-migration resettlement stressors have been linked to poor mental health in refugees (Teodorescu et al., 2012). However, perhaps no other resettlement stressor has more effects on a refugee family than unemployment. Unemployment, or underemployment, can negatively impact refugee families in multiple areas, such as income, housing, social interaction, and social status. Additionally, employment issues are associated both with the existence of a mental health diagnosis and with symptom severity (Teodorescu et al.).

This article provides an overview of refugee mental health, refugee employment issues, and the interplay between these forces. It also examines the social work practice recommendations that concurrently address refugee mental health and refugee employment issues, from literature published after Miller and Rasmussen introduced the "daily stressors" conceptual model in 2010. This article is intended to serve as a guide for social workers who want to increase their clinical, cultural, and social understanding of refugees and who want to incorporate evidence-informed recommendations into their practice with refugees.

\section{An Overview of Refugee Mental Health}

Refugees, by definition, have experienced extreme stress by the time they reach the United States for resettlement. A refugee, according to Article 1 of the 1951 Convention Relating to the Status of Refugees, is an individual, who, owing to well-founded fear of being persecuted for reasons of race, religion, nationality, membership of a particular social group or political opinion, is outside the country of his nationality and is unable or, owing to such fear, unwilling to avail himself of the protection of that country; or who, not having a nationality and being outside the country of his former habitual residence as a result of such events, is unable or, owing to such fear, unwilling to return to it.

As is suggested by the definition, before fleeing their countries of origin, refugees may well have experienced human rights violations, including war, mass violence, persecution, family separation, torture, and rape. Certainly, the experience of persecution-and/or the fear of it-underlies the refugee experience. Also, before being resettled in the US (or in any of the resettlement countries), refugees are required to have taken up residence in a second country (often in a refugee camp) where they requested, waited for, and ultimately received their refugee papers from the United Nations. Their experiences in that second country may also have been traumatic, as violence, especially against women and children, are serious concerns in refugee camps (Lischer, 2015). When experts conceptualize refugee mental health, they think of the continuum of the refugee's experience: pre-migration in the home country; migration as the refugee fled home and sought initial refuge in a second country; and post-migration in the resettlement country (Bhugra \& Jones, 2001). Mental health concerns may originate in any of these stages (Kirmayer et al., 2011).

\section{Prevalence of Mental Health Disorders in Refugee Populations}

Given their histories of trauma and dislocation, it is unsurprising that refugees have high rates of posttraumatic stress disorder (PTSD), major depressive disorder (MDD), complicated grief, and somatic disorders (Craig et al., 2008; Fazel et al., 2005; Hocking et al., 2015). In a systematic review of psychiatric research on nearly 7,000 refugees living in Western countries, the prevalence of PTSD among refugees was found to be nearly ten times as high as that in non-refugee populations (Fazel et al., 2005). And in a study of 126 Bosnian refugees resettled in the United States prevalence rates of PTSD were 66.6\%, complicated grief was 54\%, anxiety was $40 \%$, and depression was $31 \%$ (Craig et al., 2008). All these rates are higher than the relevant rates in the U.S. population as a whole (Substance Abuse and Mental Health Services Administration (SAMHSA), 2018). 
Disney \& McPherson, 2020

Comorbidity between PTSD and MDD occurs frequently in refugee populations (Teodorescu et al., 2012). Exposure to trauma, usually with the first occurrence during the pre-migration phase, is the most significant predictor of PTSD among resettled refugee populations (Kartal \& Kiropoulos, 2016). Depression, however, may be rooted in post-resettlement factors, such as language difficulties, social isolation, and unemployment issues (Ehntholt \& Yule, 2006). And although the onset of PTSD is usually prior to resettlement, the severity of symptoms has been found to be related to the extent of resettlement stress (Kartal \& Kiropoulos).

\section{Barriers to Mental Health Treatment}

Although refugees have documented mental health concerns, especially PTSD, they are less likely to access mental health services than the native-born population (Lamkaddem et al., 2014). Barriers to refugees' mental health treatment can be grouped into two broad categories: structural barriers and cultural barriers (Agrawal \& Venkatesh, 2016; Kaczorowski et al., 2011; Kirmayer et al., 2011; Moreno et al., 2006). Structural barriers make it physically difficult for people to access services and include such problems as lack of access to nearby public transportation, lack of evening or weekend hours, lack of childcare, and lack of access to services due to inadequate insurance or other means of payment. Whether structural barriers exist or not, cultural barriers, discourage the refugee's interest in or ability to seek out services or to remain in services. Examples of cultural barriers include: a lack of confidential and trained interpreter services; the absence of materials in the person's native language; lack of cultural sensitivity or knowledge from the clinician or agency; lack of explanation for Western interventions; and stigma against seeking mental health services in the refugee's cultural community. Addressing these cultural barriers and providing clinicians who are trained in the treatment of complex PTSD have been identified as factors that predict service utilization and satisfaction for refugees (Kaczorowski et al.; Moreno et al.).

\section{Effective Treatment Interventions for Refugee Populations}

Effective treatment interventions for refugee populations begin by addressing the cultural and structural barriers that impede their access to treatment. Cultural sensitivity is a key component to effective treatment, and it is both a predictor for not engaging in services (when it is lacking) and for engaging in services (when it occurs) (Al-Krenawi \& Graham, 2000). Refugees in the United States are often from cultural backgrounds that value collectivism and patriarchy. In order to be culturally sensitive, mental health practitioners should consider the client's role in the family and community, gender relations, (Al-Krenawi \& Graham), and whether the use of a family therapy modality or a systems theoretical framework is more culturally appropriate than an individualistic approach (Kira et al., 2014). Additionally, part of being sensitive to the refugee experience is for the practitioner to proactively learn about the political and human rights issues in the countries from which their clients are migrating (Engstrom \& Okamura, 2004; Kirmayer et al., 2011).

Cultural and political sensitivity is the basis of quality mental health treatment for refugees, but there are also specific interventions to be learned, and providers should practice those modalities whose effectiveness is supported by the literature. There are several evidence-based treatments for PTSD that have been found to be effective for refugees, including Trauma-Focused Cognitive Behavioral Therapy (Crumlish \& O’Rourke, 2010), Eye Movement Desensitization and Reprocessing (Acarturk et al., 2015), Prolonged Exposure (Park et al., 2020), Narrative Exposure Therapy (Crumlish \& O'Rourke; McPherson, 2012), and psychotherapy (Neuner et al., 2008). However, the empirical research base for evidence-based practices with refugee populations is not well developed, and per the American Psychological Association, evidence-based practices should be adapted according to client culture and preferences (Isakson et al., 2015).

Additionally, no one PTSD treatment modality has been found to be superior, and while trauma-informed modalities are a clinical necessity for effective treatment with traumatized populations, clinicians should also understand that the therapeutic principles of safety, coping, self- and community efficacy, connectedness, and hope have been consistently recommended by experts in the fields as key to treating refugee trauma and 
Disney \& McPherson, 2020

mental health (Hobfoll et al., 2007). Lastly, research has also explored interventions for resettlement-related stress and anxiety and found that community-based interventions can be effective (Nazzal, 2014; Murray et al., 2010; Williams \& Thompson, 2011).

\section{Overview of Employment Issues for U.S. Refugees}

When refugees arrive in the U.S. for permanent resettlement, they have already been assigned to a resettlement agency (e.g., International Rescue Committee, World Relief) that is contracted by the U.S. Office of Refugee Resettlement to provide case management and financial and/or housing services for a limited time, usually between 30 and 180 days (Farrell et al., 2008). Helping families become employed and financially independent is one of the top priorities of U.S. resettlement agencies (Codell et al., 2011).

\section{Prevalence of Unemployment and Underemployment in U.S. Refugee Populations}

National-level data shows that about half of adult refugees who are in resettlement assistance programs have jobs within eight months of arriving in the U.S. (Fix et al., 2017). Further, overall employment rates for male refugees are higher than for U.S.-born men (67\% versus 62\%; Capps et al., 2015). However, nation-wide data does not capture the nuances of the U.S. refugee population who, in 2016, came from 78 countries (Fix et al.). For example, recent data on Burmese, Iraqi, and Somali refugee groups indicate that members of these refugee communities have lower rates of employment than their U.S.-born peers (Capps et al.).

While unemployment rates for U.S. refugees are, in general, lower than for U.S. natives, refugees have higher rates of underemployment than U.S. natives (Fix et al., 2017; McAfee, 2012). Underemployment is a construct that captures several types of poor fit between an employee and his or her job, for example: (1) when a person possesses higher-level skills or more formal education than the job requires; (2) when a person has received specific training that is unrelated to the job they are doing; and (3) when a person is employed for fewer hours or in a more temporary setting than he or she wishes to be (Feldman, 1996; Verbruggen et al., 2015).

Among refugees, underemployment is associated with increased poverty (Waxman, 2001, lower self-rated health (Jamil et al., 2012), and reduced life satisfaction (George, et al., 2012); also, some argue that underemployment suppresses local economies due to wasted skills (Broadbent et al., 2007). Underemployed refugees also experience a demotion in social status when foreign-trained professionals-doctors, businesspeople, professors, and engineers-are unable to practice in their fields due to bureaucratic and other barriers. In some cases, refugees' international diplomas and licenses are not recognized in the United States, and, many times, documents have also been lost in war. Lack of English language competency can also be a barrier to becoming employed in one's field of expertise (Waxman, 2001). Even refugees who have adequate English ability may not have enough English skills to successfully navigate higher-skilled job applications and interviews (Stewart et al., 2008). Overall, almost half of Burmese, Cuban, and Iraqi refugees report underemployment (Fix et al., 2017; McAfee, 2012).

\section{A Reciprocal Relationship between Refugee Mental Health and Employment}

Unemployment and underemployment are both sources of resettlement-related stress that can affect-and can be affected by-mental health. Unemployment is a risk factor for poor mental health in the general U.S. population (Artazcoz et al., 2004) as well as in refugee populations (Ehntholt \& Yule, 2006; Marshall et al., 2005; Porter \& Haslam, 2005). Hocking et al. (2015) found that refugees with a diagnosis of MDD had more severe symptoms if they were unemployed. In a cross-sectional study of 483 Cambodian refugees, unemployment was significantly associated with higher rates of PTSD and MDD even twenty years after 
resettlement (Marshall et al., 2005). In a regression analysis study of Muslim refugees living in the Netherlands, unemployment predicted psychological distress (Fassaert et al., 2011).

The literature shows that underemployment has a negative effect on refugee life satisfaction (George et al., 2012), physical health (Jamil et al., 2012), and mental health (Lunn, 2014). In a qualitative study of Somali refugees (Lunn), one woman shared her belief that her friend's psychiatric hospitalization was the result of a socioeconomic demotion after resettlement. Baran et al.'s (2018) recent study argues that refugees develop unrealistically positive expectations about life in the US and then face intense job dissatisfaction when confronted by longterm underemployment. The hopelessness and dissatisfaction lead some to "consider abandoning their pursuit of the "American dream"” and wish for return to their home countries (p. 102). In a somewhat different study, Beiser et al. (1993) found that underemployment did not have the same negative effect on mental health for Southeast Asian refugees that it did for Canadian citizens.

While unemployment and underemployment are risk factors for mental health problems among refugees, employment is a protective factor. For example, Hocking et al. (2015) found that refugees and asylum seekers who secured employment during early resettlement reported better mental health as compared to their unemployed peers and were less likely to develop MDD. Employment has also been shown to moderate the severity of mental health concerns among refugees (Hocking et al.; Kirmayer et al., 2011; Porter \& Haslam, 2005).

\section{Effects of Refugee Mental Health on Employment}

The reciprocal relationship between mental health and employment means that not only does employment affect mental health, but also that mental health affects employment and employability (Beiser et al., 1993; Fassaert et al., 2011; Teodorescu et al., 2012; Wright et al., 2016). In a large study of 1,348 Southeast Asian refugees living in Canada, prior diagnosis of depression predicted difficulty maintaining stable employment (Beiser et al.). Interestingly, Wright and colleagues, who followed Iraqi refugees in the US over two years, found that neither the experience of pre-migration nor post-migration trauma predicted unemployment; however, refugees who experienced both pre-migration and resettlement traumas were significantly more likely to be unemployed. It is also important, if unsurprising, that refugees who experienced high levels of trauma in both periods had a much higher probability of being unemployed (91\%) than refugees with low trauma levels (20\%).

\section{Implications for Social Work Practice}

Given this reciprocal relationship between mental health and employment, social work practice must address both mental health and employment concerns.

\section{Recommendations for Social Work Clinicians}

Empirical studies consistently conclude that clinical social workers should understand that assisting refugees towards full and meaningful employment is a mental health intervention (Murray et al., 2010; Williams \& Thompson, 2011). Mental health professionals should expand their focus to include refugee resettlement stressors, rather than focusing primarily on addressing trauma-related symptoms (Murray et al.; Weine, 2011). This expansion in clinical focus, which is beginning to happen (Nazzal et al., 2014), has shed light on the complex and frequent challenges that refugees face during resettlement, including navigating a multitude of new systems to find housing, seek healthcare, enroll children in school, use transportation, and obtain employment, etc. In many ways, helping refugees meet their human needs is a practical approach for working with refugees, especially for social workers who may not be trained in treating complex trauma. 
Disney \& McPherson, 2020

Additionally, this shift allows social workers to create relationships with refugees around concerns that may not trigger the same stigma as mental health services (Kaczorowski et al., 2011; Nazzal et al., 2014; Moreno et al., 2006). Social workers who are focused on the totality of the refugee's concerns-and practice both therapy and case management-may be trusted to address mental health problems when they arise. Lastly, clinical social workers should inquire about employment-related stressors during assessment, the timing of the onset of mental health problems, and the extent to which the presenting problem may be related to resettlement stressors in order to best conceptualize the case and achieve an accurate diagnosis (Schbley \& Kaufman, 2012).

\section{Recommendations for Social Workers in Resettlement Practice}

Refugee resettlement agencies are at times criticized for not adequately meeting the needs of their clients (Sossou et al., 2008), yet funding limitations and, in some places, anti-refugee sentiments and political resistance, can be barriers for resettlement professionals who strive to help their clients (Capps et al., 2015; Weine, 2011). Traditionally, the guiding principle for U.S. refugee resettlement has been "work first." As a result, resettlement agencies may become overly focused on immediate employment and then overlook strategies that would help refugees find satisfying, longterm work, like English classes and mental health support (Capps et al.; Fix et al., 2017). A common recommendation to combat limited resources is for resettlement agencies to engage in more partnerships with voluntary agencies (Mott, 2010), such as recruiting BSW or MSW interns (Goodkind et al., 2014), or partnering with local faith communities (Eby et al., 2011).

Resettlement agencies should take an active role in helping find employment not only for their direct clients, but also for the relatives of their clients and their clients from the past (Tran, 1991). Resettlement agencies could also expand their employer partnerships to not only place, but also continue to support new hires (Capps et al., 2015). New employer partnerships may be more easily obtained if resettlement agencies provide local employers clear and accessible information on refugees and refugees' rights to work (Migration Policy).

English language fluency was frequently cited as a major factor in refugee employment and, to a lesser extent, on refugee mental health (Beiser, 2006; Stewart et al., 2008). Empirical research substantiates the hypothesis that a lack of English proficiency is a significant predictor of both mental health problems and unemployment among refugees (Beiser; Campbell et al., 2018), and qualitative research explains the interconnectedness of being able to communicate in English with social connection, reduced feelings of sadness, and ability to find work (Disney et al., 2016). Some refugees, especially those who are college-educated and skilled workers, may have basic English language ability but lack the advanced English needed to succeed in a professional-level job market. Thus, resettlement agencies can offer higher-level English classes; they can also support Englishlearning by establishing one-on-one language partnerships between refugees and local ESL volunteers or college students who are interested in learning the other language (Stewart et al., 2008). Finally, it is important that the US extend the timeframe for refugee financial assistance so that refugees can attend English classes (Stewart et al.).

Newly arrived refugees in communities with established social networks from their countries of origin are more likely to be employed and with a higher hourly wage than refugees whose networks consist only of newly arrived refugees (Beaman, 2012). Research also supports that social connection is a protective factor against MDD (Goodkind et al., 2014). A logical conclusion to these findings is that resettling refugees in established refugee communities-rather than spreading new arrivals across the United States-is more beneficial to refugees' long-term resettlement successes.

\section{Recommendations for Social Work Policymakers}

As mentioned previously, the U.S. refugee resettlement program focuses funding on employment, while disregarding the need for refugees to dedicate time to learn English, have their foreign credentials validated, 
or take courses to become credentialed in their profession in the United States (Capps et al., 2015; Fix et al., 2017). Several researchers (Capps et al.; Fix et al.) conclude that while these policies help refugees become employed, they also inadvertently support refugees being underemployed by not taking their skills and diplomas into account. Policymakers should advocate for expanded funding that would support English language acquisition, job training programs, and career counseling services (Capps et al.; Stewart, 2007). Lastly, federal initiatives could encourage resettlement agencies to increase their collaborations locally with both employers and mental health agencies (Weine, 2011).

The literature recommends improving refugee mental health access and prevention services (Agrawal \& Venkatesh, 2016; Weine, 2011). For example, policymakers should consider policy changes to improve refugee health insurance access. Given that Medicaid programs vary greatly from state to state, federal agencies could consider the availability of state Medicaid programs when determining where to resettle refugees, to ensure their access to mental health treatment (Agrawal \& Venkatesh). The federal government should also consider policies that would incentivize states to expand Medicaid access for refugees (Agrawal \& Venkatesh).

\section{Recommendations for Social Work Researchers}

As documented previously, research supports a reciprocal or interactive relationship between refugee employment and mental health. However, there is a dearth of longitudinal studies that focus on refugee mental health issues, refugee employment issues, or the interaction between refugee mental health and refugee employment. Longitudinal studies are needed to understand what is unique to the refugee population. For example, an abundance of research confirms the relationship between English language proficiency and employability, yet one recent longitudinal study of 233 refugee men in Australia found, surprisingly, that English language proficiency was not a significant predictor of employment (Correa-Velez et al., 2015). More research is needed to truly understand this complex interaction.

Another recommendation for social work researchers is the need for a nationally coordinated effort to collect standardized state-level data to understand the various compounding factors that affect refugee employment and mental health. Additionally, employment is not a simple dichotomous variable. Beyond employment and unemployment, it is also important to understand underemployment. Lastly, researchers should report detailed employment statistics that distinguish between inadequate employment and meaningful employment and between refugee groups (Codell et al., 2011).

\section{Conclusion}

Employment and mental health are inextricably bound. Social workers who engage professionally with refugees in any context should consider the individuals' educational and vocational histories and current employment status when assessing the inter-relationship between refugee's mental health and employment experiences (Beiser, 2009). As this article makes clear, social workers must understand the role of employment in refugee mental health and the reality that mental health factors contribute to a refugee's ability to find and maintain work. Social workers must look closely to see the differences between those who are at risk for mental health issues and those who are at risk for employment-related stress and then tailor interventions accordingly. The changes described here are needed to improve refugees' post-migration resettlement experiences and will have positive impacts on the lives of U.S. refugees.

\section{References}

Acarturk, C., Konuk, E., Cetinkaya, M., Senay, I., Sijbrandij, M., Cuijpers, P., \& Aker, T. (2015). EMDR for Syrian refugees with posttraumatic stress disorder symptoms: Results of a pilot randomized 
controlled trial. European Journal of Psychotraumatology, 6(1), 27414. https://doi.org/10.3402/ejpt.v6.27414

Agrawal, P., \& Venkatesh, A. K. (2016). Refugee resettlement patterns and state-level health care insurance access in the United States. American Journal of Public Health, 106(4), 662-663. https://doi.org/10.2105/AJPH.2015.303017

Al-Krenawi, A., \& Graham, J. R. (2000). Culturally sensitive social work practice with Arab clients in mental health settings. Health \& Social Work, 25(1), 9-22. https://doi.org/10.1093/hsw/25.1.9

Artazcoz, L., Benach, J., Borrell, C., \& Cortès, I. (2004). Unemployment and mental health: Understanding the interactions among gender, family roles, and social class. American Journal of Public Health, 94(1), 82-88. https://doi.org/10.2105/AJPH.94.1.82

Baran, B. E., Valcea, S., Porter, T. H. \& Gallagher, V. C. (2018). Survival, expectations, and employment: An inquiry of refugees and immigrants to the United States. The Journal of Vocational Behavior, 105, 102-115. https://doi.org/10.1016/j.jvb.2017.10.011

Beaman, L. A. (2012). Social networks and the dynamics of labour market outcomes: Evidence from refugees resettled in the U.S. Review of Economic Studies, 79(1), 128-161. https://doi.org/10.1093/restud/rdro17

Beiser, M. (2006). Longitudinal research to promote effective refugee resettlement. Transcultural Psychiatry, 43(1), 56-71. https://doi.org/10.1177/1363461506061757

Beiser, M. (2009). Resettling refugees and safeguarding their mental health: Lessons learned from the Canadian Refugee Resettlement Project. Transcultural Psychiatry, 46(4), 539-583. https://doi.org/10.1177/1363461509351373

Beiser, M., Johnson, P. J., \& Turner, R. J. (1993). Unemployment, underemployment and depressive affect among Southeast Asian refugees. Psychological Medicine, 23(03), 731-743. https://doi.org/10.1017/So033291700025502

Bhugra, D., \& Jones, P. (2001). Migration and mental illness. Advances in Psychiatric Treatment, 7(3), 216222. https://doi.org/10.1192/apt.7.3.216

Broadbent, R., Cacciattolo, M., \& Carpenter, C. (2007). A tale of two communities: refugee relocation in Australia. Australian Journal of Social Issues, 42(4), 581-601. https://doi.org/10.1002/j.18394655.2007.tb00079.x

Campbell, M. R., Mann, K. D., Moffatt, S., Dave, M., \& Pearce, M. S. (2018). Social determinants of emotional well-being in new refugees in the UK. Public Health, 164, 72-81. https://doi-org.proxyremote.galib.uga.edu/10.1016/j.puhe.2018.07.022

Capps, R., Newland, K., Fratzke, S., Groves, S., Auclair, G., Fix, M., \& McHugh, M. (2015). The integration outcomes of US refugees: Successes and challenges. Migration Policy Institute.

Codell, J. D., Hill, R. D., Woltz, D. J., \& Gore, P. A. (2011). Predicting meaningful employment for refugees: The influence of personal characteristics and developmental factors on employment status and hourly wages. International Journal for the Advancement of Counselling, 33(3), 216. https://doi.org/10.1007/s10447-011-9125-5

Correa-Velez, I., Barnett, A. G., \& Gifford, S. (2015). Working for a better life: Longitudinal evidence on the predictors of employment among recently arrived refugee migrant men living in Australia. International Migration, 53(2), 321-337. https://doi.org/10.1111/imig.12099

Craig, C. D., Sossou, M.-A., Schnak, M., \& Essex, H. (2008). Complicated grief and its relationship to mental health and well-being among Bosnian refugees after resettlement in the United States: Implications 
for practice, policy, and research. Traumatology, 14(4), 103-115. https://doi-org.proxyremote.galib.uga.edu/10.1177/1534765608322129

Crumlish, N., \& O'Rourke, K. (2010). A systematic review of treatments for post-traumatic stress disorder among refugees and asylum-seekers. The Journal of Nervous and Mental Disease, 198(4), 237-251. 10.1097/NMD.obo13e3181d61258

Disney, L., McPherson, J. \& Jamal, Z. (2016, June). The effects of underemployment on Iraqi refugees' adaption to the U.S. and life satisfaction [Discussion Forum Presentation]. Work and Family Researchers Network Conference, Washington, D.C.

Eby, J., Iverson, E., Smyers, J., \& Kekic, E. (2011). The faith community's role in refugee resettlement in the United States. Journal of Refugee Studies, 24(3), 586-605. https://doi.org/10.1093/jrs/fero38

Ehntholt, K. A., \& Yule, W. (2006). Practitioner review: Assessment and treatment of refugee children and adolescents who have experienced war-related trauma. Journal of Child Psychology and Psychiatry, 47(12), 1197-1210. https://doi.org/10.1111/j.1469-7610.2006.01638.x

Engstrom, D.W. \& Okamura, A. (2004). A plague of our time: Torture, human rights, and social work. Families in Society, 85, 291-300. https://doi.org/10.1177/104438940408500303

Farrell, M., Barden, B., \& Mueller, M. (2008). The evaluation of the Refugee Social Service (RSS) and Targeted Assistance Formula Grant (TAG) programs: Synthesis of findings from three sites. The Lewin Group, prepared for US Department of Health and Human Services, Office of Refugee Resettlement. https://www.acf.hhs.gov/sites/default/files/orr/synthesisoffindingsfromthreesites.pdf

Fassaert, T., De Wit, M. A., Tuinebreijer, W. C., Knipscheer, J. W., Verhoeff, A. P., Beekman, A. T., \& Dekker, J. (2011). Acculturation and psychological distress among non-Western Muslim migrants-A population-based survey. International Journal of Social Psychiatry, 57(2), 132-143. https://doi.org/10.1177/0020764009103647

Fazel, M.; Wheeler, J., \& Danesh J. (2005). Prevalence of serious mental disorder in 7000 refugees resettled in western countries: A systematic review. Lancet, 365, 1309-1314. https://doi.org/10.1016/So140$\underline{6736(05) 61027-6}$

Feldman, D. C. (1996). The nature, antecedents and consequences of underemployment. Journal of Management, 22(3), 385-407. https://doi.org/10.1177/014920639602200302

Fix, M., Hooper, K., \& Zong, J. (2017). How are refugees faring? Integration at U.S. and state levels. Migration Policy Institute. https://www.migrationpolicy.org/research/how-are-refugees-faringintegration-us-and-state-levels

George, U., Chaze, F., Fuller-Thomson, E., \& Brennenstuhl, S. (2012). Underemployment and life satisfaction: A study of internationally trained engineers in Canada. Journal of Immigrant \& Refugee Studies, 1O(4), 407-425. https://doi.org/10.1080/15562948.2012.717827

Goodkind, J. R., Hess, J. M., Isakson, B., LaNoue, M., Githinji, A., Parker, D. P., Roche, N., Vadnais, K. (2014). Reducing refugee mental health disparities: A community-based intervention to address postmigration stressors with African adults. Psychological Services, 11(3), 333-346. https://doi.org/10.1037/a0035081

Hobfoll, S. E., Watson, P., Bell, C. C., Bryant, R. A., Brymer, M. J., Friedman, M. J., Friedman, M., Gersons, B. P. R., de Jong, J. T. V. M., Layne, C. M., Maguen, S., Neria, Y., Norwood, A. E., Pynoos, R. S., Reissman, D., Ruzek, J. I., Shalev, A. Y., Solomon, Z., Steinberg, A. M., \& Ursano, R. J. (2007). Five essential elements of immediate and mid-term mass trauma intervention: Empirical evidence. Psychiatry: Interpersonal and Biological Processes, 70(4), 283-315. https://doi.org/10.1521/psyc.2007.70.4.283 
Disney \& McPherson, 2020

Hocking, D. C., Kennedy, G. A., \& Sundram, S. (2015). Mental disorders in asylum seekers: The role of the refugee determination process and employment. The Journal of Nervous and Mental Disease, 203(1), 28-32. https://doi.org/10.1097/NMD.0000000000000230

Isakson, B. L., Legerski, J. P., \& Layne, C. M. (2015). Adapting and implementing evidence-based interventions for trauma-exposed refugee youth and families. Journal of Contemporary Psychotherapy, 45(4), 245-253. https://doi.org/10.1007/s10879-015-9304-5

Jamil, H., Aldhalimi, A., \& Arnetz, B. B. (2012). Employment satisfaction and health outcomes among professional Iraqi refugees as compared to immigrants. Journal of Immigrant \& Refugee Studies, $10(4), 395$.

Kaczorowski, J. A., Williams, A. S., Smith, T. F., Fallah, N., Mendez, J. L., \& Nelson-Gray, R. (2011). Adapting clinical services to accommodate needs of refugee populations. Professional Psychology: Research \& Practice, 42(5), 361-367. doi:10.1037/a0025022

Kartal, D., \& Kiropoulos, L. (2016). Effects of acculturative stress on PTSD, depressive, and anxiety symptoms among refugees resettled in Australia and Austria. European Journal of Psychotraumatology, 7. https://doi.org/10.3402/ejpt.v7.28711

Kira, I. A., Amer, M. M., \& Wrobel, N. H. (2014). Arab refugees: Trauma, resilience, and recovery. In Biopsychosocial perspectives on Arab Americans (pp. 175-195). Springer.

Kirmayer, L. J., Narasiah, L., Munoz, M., Rashid, M., Ryder, A. G., Guzder, J., \& Pottie, K. (2011). Common mental health problems in immigrants and refugees: General approach in primary care. Canadian Medical Association Journal, 183(12), E959-E967. https://doi.org/10.1503/cmaj.090292

Lamkaddem, M., Stronks, K., Devillé, W. D., Olff, M., Gerritsen, A. A., \& Essink-Bot, M. L. (2014). Course of post-traumatic stress disorder and health care utilisation among resettled refugees in the Netherlands. BMC psychiatry, 14(1), 90. https://doi.org/10.1186/1471-244X-14-90

Lischer, S. K. (2015). Dangerous sanctuaries: Refugee camps, civil war, and the dilemmas of humanitarian aid. Cornell University Press.

Lunn, L. M. (2014). The social determinants of refugee health: An integrated perspective [Unpublished doctoral dissertation]. Vanderbilt University. https://ir.vanderbilt.edu/handle/1803/etd-07172014$\underline{213543}$

Marshall, G. N., Schell, T. L., Elliott, M. N., Berthold, S. M., \& Chun, C. A. (2005). Mental health of Cambodian refugees 2 decades after resettlement in the United States. Jama, 294(5), 571-579.

McAfee, H. (2012). Identity-making and "home": Resettlement of post-2003 Iraqi refugees in Portland, Oregon and Austin, Texas [Unpublished master's thesis]. University of Oregon.

McPherson, J. (2012). Does narrative exposure therapy reduce PTSD in survivors of mass violence? Research on Social Work Practice, 22(1), 29-42. https://doi.org/10.1177/1049731511414147

Miller, K. , \& Rasmussen, A. (2010). War exposure, daily stressors, and mental health in conflict and postconflict settings: bridging the divide between trauma-focused and psychosocial frameworks. Social Science \& Medicine, 70(1), 7-16. https://doi.org/10.1016/j.socscimed.2009.09.029

Miller, K. E., \& Rasmussen, A. (2014). War experiences, daily stressors and mental health five years on: Elaborations and future directions. Intervention, 12, 33-42. https://www.interventionjournal.com

Moreno, A., Piwowarczyk, L., LaMorte, W. W., \& Grodin, M. A. (2006). Characteristics and utilization of primary care services in a torture rehabilitation center. Journal of Immigrant and Minority Health, 8(2), 163-171. https://doi.org/10.1007/s10903-006-8524-x 
Mott, T. E. (2010). African refugee resettlement in the US: the role and significance of voluntary agencies. Journal of Cultural Geography, 27(1), 1-31. https://doi.org/10.1080/08873631003593190

Murray, K. E., Davidson, G. R., \& Schweitzer, R. D. (2010). Review of refugee mental health interventions following resettlement: Best practices and recommendations. American Journal of Orthopsychiatry, 8o(4), 576-585. https://doi.org/10.1111/j.1939-0025.2010.01062.x

Nazzal, K. H., Forghany, M., Geevarughese, M. C., Mahmoodi, V., \& Wong, J. (2014). An innovative community-oriented approach to prevention and early intervention with refugees in the United States. Psychological Services, 11(4), 477. https://doi.org/10.1037/a0037964

Neuner, F., Onyut, P. L., Ertl, V., Odenwald, M., Schauer, E., \& Elbert, T. (2008). Treatment of posttraumatic stress disorder by trained lay counselors in an African refugee settlement: A randomized controlled trial. Journal of Consulting and Clinical Psychology, 76(4), 686. http://dx.doi.org/10.1037/0022006X.76.4.686

Park, J. K., Park, J., Elbert, T., \& Kim, S. J. (2020). Effects of narrative exposure therapy on posttraumatic stress disorder, depression, and insomnia in traumatized North Korean refugee youth. Journal of Traumatic Stress, 3O, 353-359. https://doi.org/10.1002/jts.22492

Porter, M., \& Haslam, N. (2005). Predisplacement and postdisplacement factors associated with mental health of refugees and internally displaced persons: A meta-analysis. JAMA, 294(5), 602-612. https://doi.org/10.1001/jama.294.5.602

Schbley, B., \& Kaufman, M. (2012). Social work practice with Arab Muslim women living in Western societies. The Journal of Practice Teaching and Learning, 7(2), 25-38. 10.1921/175951506784477717

Sossou, M.-A., Craig, C., Ogren, H., \& Schnak, M. (2008). A qualitative study of resilience factors of Bosnian refugee women resettled in the southern United States. Journal of Ethnic \& Cultural Diversity in Social Work, 17(4), 365. https://doi.org/10.1080/15313200802467908

Stewart, M., Anderson, J., Beiser, M., Mwakarimba, E., Neufeld, A., Simich, L., \& Spitzer, D. (2008). Multicultural meanings of social support among immigrants and refugees. International Migration, 46(3), 123-159. https://doi.org/10.1111/j.1468-2435.2008.00464.x

Stewart, E. (2007). Addressing the challenges facing refugee doctors in the UK. Local Economy, 22(4), 409-417. 10.1080/02690940701736868

Substance Abuse and Mental Health Services Administration. (2018). Key substance use and mental health indicators in the United States: Results from the 2017 National Survey on Drug Use and Health (HHS Publication No. SMA 18-5068, NSDUH Series H-53). Center for Behavioral Health Statistics and Quality, Substance Abuse and Mental Health Services Administration. https://www.samhsa.gov/data/

Teodorescu, D. S., Heir, T., Hauff, E., Wentzel-Larsen, T. O. R. E., \& Lien, L. (2012). Mental health problems and post-migration stress among multi-traumatized refugees attending outpatient clinics upon resettlement to Norway. Scandinavian Journal of Psychology, 53(4), 316-332. https://doi.org/10.1111/j.1467-9450.2012.00954.x

Tran, T. V. (1991). Sponsorship and employment status among Indochinese refugees in the United States. International Migration Review, 25(3), 536-550.

United Nations High Commissioner for Refugees. (2018). Resettlement. USA. http://www.unhcr.org/enus/resettlement.html

Verbruggen, M., van Emmerik, H., Van Gils, A., Meng, C., \& de Grip, A. (2015). Does early-career underemployment impact future career success? A path dependency perspective. Journal of Vocational Behavior, 90, 101-110. http://dx.doi.org/10.1016/j.jvb.2015.08.002. 
Waxman, P. (2001). The economic adjustment of recently arrived Bosnian, Afghan and Iraqi refugees in Sydney, Australia. International Migration Review, 35(2), 472-505.

Weine, S. M. (2011). Developing preventive mental health interventions for refugee families in resettlement. Family Process, 5o(3), 410-430. https://doi.org/10.1111/j.1545-5300.2011.01366.x

Williams, M. E., \& Thompson, S. C. (2011). The use of community-based interventions in reducing morbidity from the psychological impact of conflict-related trauma among refugee populations: A systematic review of the literature. Journal of Immigrant and Minority Health, 13(4), 780-794. https://doi.org/10.1007/s10903-010-9417-6

Wright, A. M., Dhalimi, A., Lumley, M. A., Jamil, H., Pole, N., Arnetz, J. E., \& Arnetz, B. B. (2016). Unemployment in Iraqi refugees: The interaction of pre- and post-displacement trauma. Scandinavian Journal of Psychology, 57(6), 564-570. https://doi.org/10.1111/sjop.12320

The Journal of Social Work in the Global Community, sponsored by the College of Social and Behavioral Sciences at Walden University, is a peer-reviewed journal and recognizes that social work is a global phenomenon with a myriad of contributors and perspectives. The journal is open to social work practice and research both domestically and abroad. 